\title{
Pengaruh Ketebalan terhadap Kekakuan pada Ring Fiksasi Eksternal Tulang Tibia
}

\author{
(The Effect of Thickness to Stiffness on Tibia External Fixation Ring)
}

Krisdiyanto ${ }^{\mathrm{a}}$

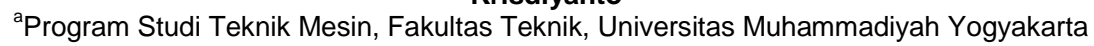
Jl. Brawijaya, Kasihan, Bantul, Yogyakarta 55183 e-mail: krisdiyanto@umy.ac.id

\begin{abstract}
Abstrak
Fiksasi eksternal adalah perangkat yang digunakan untuk menjaga posisi fracture pada tulang stabil. Perangkat tersebut dipasang di luar soft tissue. Komponen utama fiksasi eksternal terdiri atas pin, clamp, dan rod. Fiksasi eksternal yang menggunakan rod lebih dari dua biasanya menggunakan ring sebagai penghubung. Jumlah rod pada fiksasi eksternal mempengaruhi kekakuan perangkat tersebut. Kekakuan fiksasi eksternal perlu dipertimbangkan agar posisi fracture tetap stabil. Modifikasi kekakuan pada fiksasi eksternal dapat dilakukan dengan memodifikasi dimensi komponen-komponen fiksasi eksternal. Simulasi pemberian gaya pada fiksasi eksternal dapat dilakukan dengan perangkat lunak berbasis finite element. Gaya yang dipakai sebagai beban dan displacement yang terjadi dapat dipakai untuk menghitung kekakuan fiksasi eksternal. Hasil penelitian ini menunjukan hasil simulasi perubahan ketebalan ring fiksasi eksternal akan memengaruhi kekakuan fiksasi eksternal.
\end{abstract}

Kata kunci: Finite Element, Displacement, Kekakuan, Tegangan

\begin{abstract}
External fixation is a device that is used to keep fracture stability. External fixation is placed out of soft tissue. Pin, clamp, and rod are main components of the external fixation. External fixation that consist of two or more rods usually uses ring as connector. The number of rods affect external fixation stiffness. External fixation stiffness should be kept because healing process is affected by fracture stability. External fixation stiffness can be modified by components dimension modifications. Testing simulations of external fixation uses finite element software. Force that used as load and displacement can be used to calculate external fixation stiffness. The results of this research is external fixation ring thickness affects external fixation stiffness.
\end{abstract}

Keywords: Finite Element, Displacement, Stiffness, Stress

\section{Pendahuluan}

Fiksasi eksternal adalah perangkat yang digunakan untuk menjaga posisi fracture pada tulang stabil. Perangkat tersebut dipasang di luar soft tissue. Komponen utama fiksasi eksternal terdiri dari pin,clamp, dan rod [1]. Perangkat tersebut mempunyai keuntungan suplai darah tidak terganggu sehingga proses penyembuhan pada kasus fracture yang disertai dengan kondisi soft tissue yang rusak atau open fracture [1]. Kasus open fracture pada tulang panjang paling banyak terjadi pada tulang tibia [2]. Kestabilan fiksasi eksternal perlu dijaga sehingga posisi fracture tidak bergeser. Kestabilan fiksasi eksternal dapat diatur dengan memodifikasi atau mengubah jumlah komponen pada fiksasi eksternal tersebut. Proses modifikasi fiksasi eksternal berawal di awal abad ke-20 dan mulai berkembang dengan cepat karena adanya kasus kegagalan penyembuhan open fracture korban Perang Dunia II [3]. Penambahan jumlah pin pada fiksasi eksternal dapat menambah nilai kekakuan dari perangkat tersebut [4]. Penambahan jumlah pin harus mempertimbangkan modifikasi bentuk clamp [5]. Penelitian yang dilakukan Sternick dkk. menggunakan standar ASTM F 1541-02 yang berjudul Standard Specification and Test Methods for External Skeletal 
Fixation Devices. Penambahan jumlah rod pada perangkat fiksasi eksternal juga akan menambah nilai kekakuan perangkat tersebut [6].

Professor Gavril A. Ilizarov dari Siberia menambahkan sebuah komponen external fixation yang disebut ring pada tahun 1952. Ring digunakan sebagai penghubung beberapa rod yang dipakai pada fiksasi eksternal untuk menambah nilai kekakuan perangkat tersebut $[7,8]$. Penambahan komponen pada perangkat fiksasi eksternal akan menambah massa perangkat tersebut. Skema pengujian kekakuan ring fiksasi eksternal terdapat pada ASTM F 1541-02. Nilai kekakuan tidak bisa dijadikan nilai keamanan perangkat fiksasi eksternal [7]. Penelitian di bidang fiksasi eksternal perlu dilakukan untuk mengurangi risiko kegagalan penyembuhan open fracture. Pengambilan nilai gaya dan tegangan yang terjadi pada perangkat fiksasi eksternal dapat dihitung dengan simulasi pada software yang berbasis finite element [8]. Penelitian ini mempunyai tujuan mendapatkan hubungan ketebalan ring terhadap kekakuan sehingga dapat digunakan sebagai acuan dalam membuat desain ring fiksasi eksternal.

\section{MetOde}

Perhitungan nilai kekakuan ring pada fiksasi eksternal dimulai dengan proses pembuatan geometri komponen tersebut dengan perangkat lunak CAD. Skema geometri yang dibuat mengacu pada standar ASTM F 1541-02. Contoh geometri yang dibuat ditampilkan pada Gambar 2.1 dan variasi geometri ditampilkan pada Tabel 2.1. Geometri tersebut kemudian di-import ke perangkat lunak yang berbasis finite element. Geometri tersebut diberi gaya sampai nilai von mises yang terjadi nilainya sama dengan yield strength material yang digunakan. Perangkat lunak yang digunakan untuk proses simulasi pemberian gaya pada geometri yaitu Autodesk Inventor Profesional dan Fusion 360. Gaya yang dipakai ketika nilai von mises dibagi displacement arah sumbu y merupakan nilai kekakuan geometri tersebut [9].

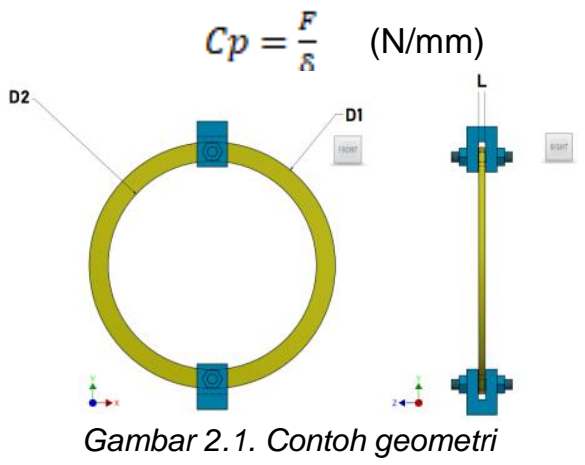

Gambar 2.1. Contoh geometri

Tabel 2.1. Variasi geometri

\begin{tabular}{ccc}
\hline No. & L/D1 & Massa (kg) \\
\hline 1 & 0,005 & 0.065 \\
2 & 0,010 & 0.131 \\
3 & 0,015 & 0.196 \\
4 & 0,020 & 0.262 \\
5 & 0,025 & 0.327 \\
\hline
\end{tabular}

Material yang digunakan yaitu stainless steel seri 316L. Pemakaian material stainless steel 316L sebagai komponen fiksasi eksternal karena material tersebut sesuai dengan standar yang peralatan medis [10]. Sifat mekanik material tersebut ditampilkan pada Tabel 2.2. Sifat mekanik stainless steel 316L didapatkan dari dokumen ASTM A240/A [11].

Tabel 2.2. Sifat mekanik stainless steel seri $316 L$

\begin{tabular}{ccc}
\hline Modulus Elastisitas (GPa) & Poison Ratio & Yield Strength (MPa) \\
\hline 192 & 0,3 & 170 \\
\hline
\end{tabular}




\section{HASIL DAN PEMBAHASAN}

Hasil simulasi pemberian gaya pada geometri menggunakan perangkat lunak Autodesk Inventor dan Fusion 360 berupa distribusi tegangan dan distribusi displacement. Distribusi tegangan yang terjadi ketika nilai maksimal von mises pada geometri sama dengan nilai yield strength material ditampilkan pada Gambar 3.1 dan displacement yang terjadi ditampilkan pada Gambar 3.2.
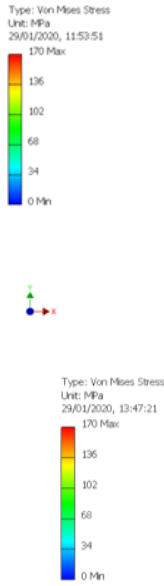

$\therefore$

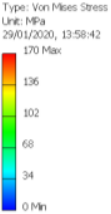

$\therefore$

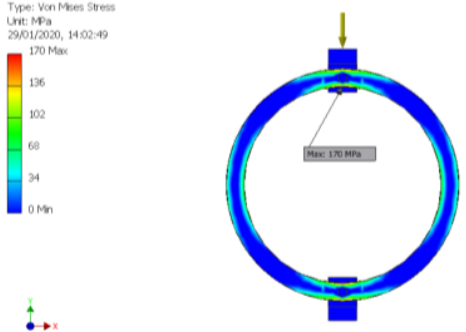

(d)

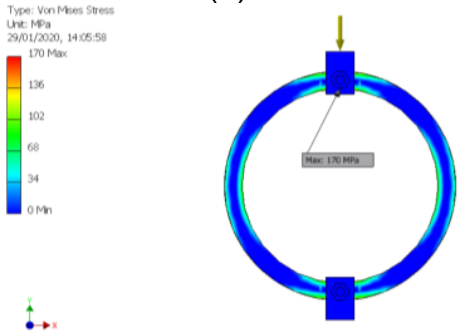

(e)

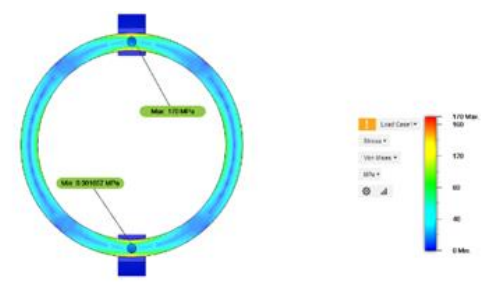

(f)

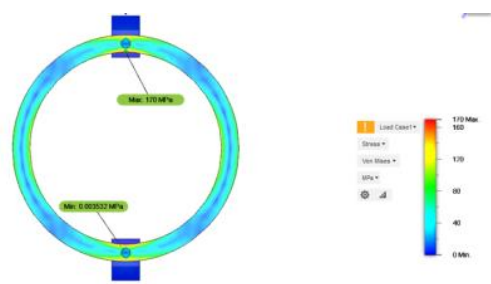

(g)

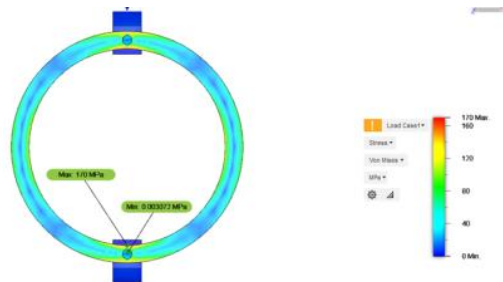

(h)

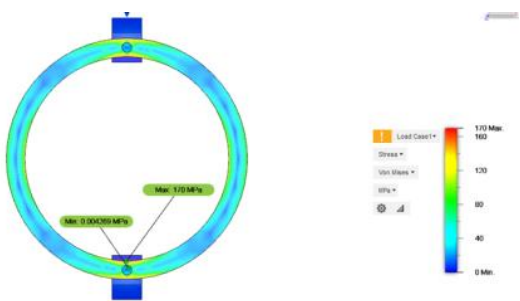

(i)
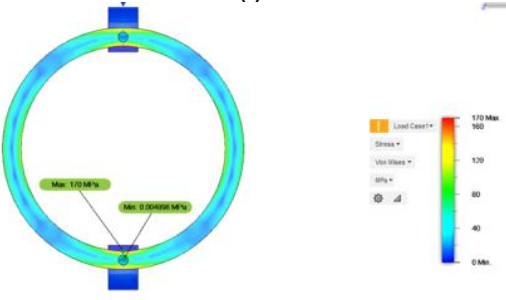

(j)

Gambar 3.1. Distribusi von mises hasil simulasi Autodesk Inventor pada variasi $L / D 1=0,005$ (a), $L / D 1=0,010$ (b), $L / D 1=0,015$ (c), $L / D 1=0,020$ (d), $L / D 1=0,025$ (e) hasil simulasi Fusion 360 pada variasi $L / D 1=0,005$ (f), $L / D 1=0,010(g), L / D 1=0,015$ (h), $L / D 1=0,020$ (i), $L / D 1=0,025$ 


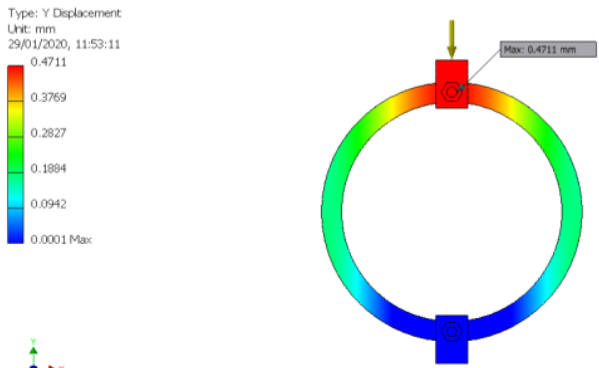

(a)

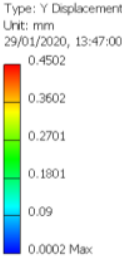

$\therefore \times$

Type: $Y$ Desplacement
Unit: $\mathrm{mm}$

Unit: $\mathrm{mm}$
$2901 / 2020,13: 57: 57$

$\prod_{0.3733}^{0.4654}$

$-0.2793$

0.1862

0.0931

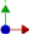

Type: $\mathrm{Y}$ Oisplacement
hhe: $\mathrm{mm}$

Whe mm $\mathrm{mm}$.

$\pi^{0.4647}$

0.3718

0.2786

0.1859

0.0929

$\stackrel{\leftrightarrow}{\circ}$

Yype: Y Desplacerment

Int: mm 1:00

$\Gamma^{0.3733}$

0.28

0.1867

0.0933

$\rightarrow x$

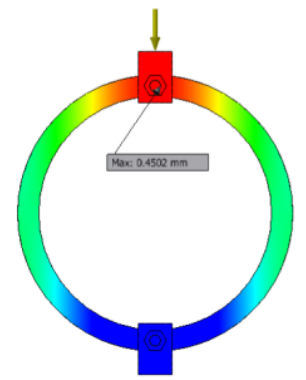

(b)

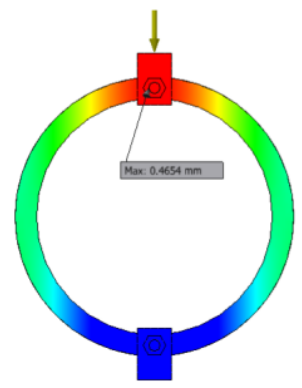

(c)

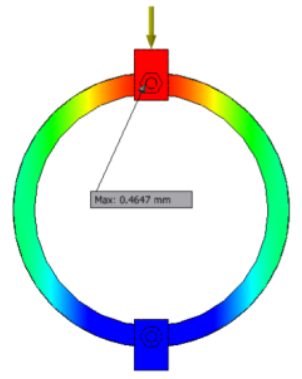

(d)

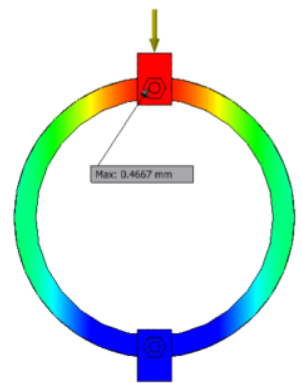

(e)
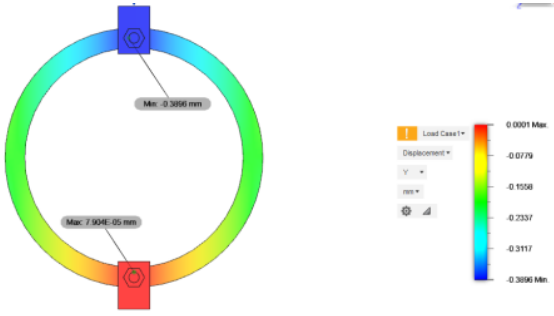

(f)

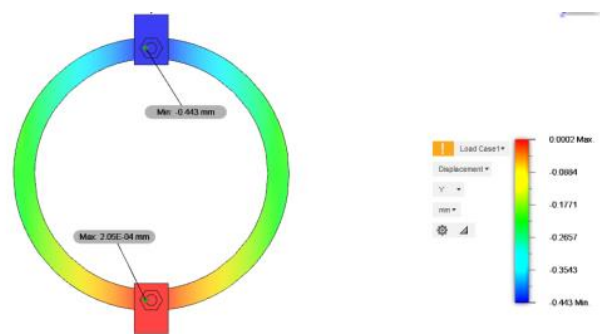

(g)
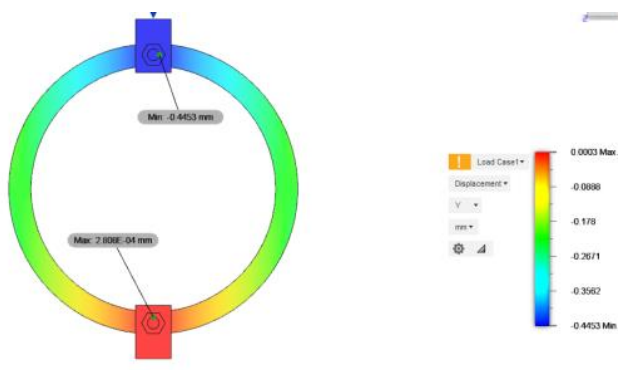

(h)
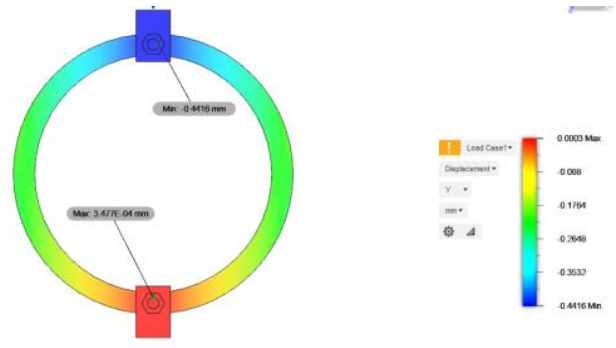

(i)
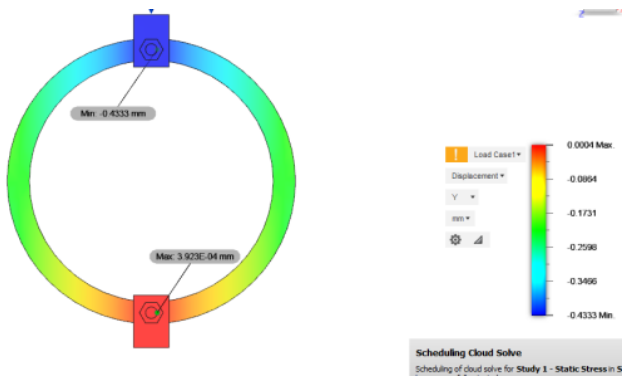

(j)

Gambar 3.2. Distribusi displacement hasil simulasi Autodesk Inventor pada variasi $L / D 1=0,005$ (a), $L / D 1=0,010$ (b), $L / D 1=0,015$ (c), $L / D 1=0,020$ (d), $L / D 1=0,025$ (e) dan hasil simulasi Fusion 360 pada variasi $L / D 1=0,005$ (f), $L / D 1=0,010(g), L / D 1=0,015$ (h), $L / D 1=0,020$ (i), $L / D 1=0,025$ (j) 
Data hasil simulasi pemberian gaya pada geometri menggunakan perangkat lunak Autodesk Inventor ditampilkan pada Tabel 3.1 dan Fusion 360 pada Tabel 3.2. Hubungan antara variasi geometri dan nilai kekakuan ring ditampilkan pada Gambar 3.3. Variasi nilai L pada ring memengaruhi nilai massa ring. Hubungan massa ring terhadap kekakuan ditampilkan pada Gambar 3.4. Nilai kekakuan yang tersaji pada Tabel 3.1 dan Tabel 3.2 merupakan hasil perhitungan dengan menggunkan persamaan (1).

Tabel 3.1. Data hasil simulasi menggunakan Autodesk Inventor

\begin{tabular}{cccccc}
\hline No. & L/D1 & $\begin{array}{c}\text { Massa } \\
(\mathrm{kg})\end{array}$ & Gaya $(\mathrm{N})$ & $\begin{array}{c}\text { Displacement } \\
(\mathrm{mm})\end{array}$ & $\begin{array}{c}\text { Kekakuan } \\
(\mathrm{N} / \mathrm{mm})\end{array}$ \\
\hline 1 & 0,005 & 0.065 & 224,45 & 0,4711 & 476,44 \\
2 & 0,010 & 0.131 & 431,14 & 0,4502 & 957,67 \\
3 & 0,015 & 0.196 & 673,27 & 0,4654 & 1446,64 \\
4 & 0,020 & 0.262 & 894,27 & 0,4647 & 1924,39 \\
5 & 0,025 & 0.327 & 1123,60 & 0,4667 & 2407,53 \\
\hline
\end{tabular}

Tabel 3.2. Data hasil simulasi menggunakan Fusion 360

\begin{tabular}{cccccc}
\hline No & L/D1 & $\begin{array}{c}\text { Massa } \\
(\mathrm{kg})\end{array}$ & Gaya $(\mathrm{N})$ & $\begin{array}{c}\text { Displacement } \\
(\mathrm{mm})\end{array}$ & $\begin{array}{c}\text { Kekakuan } \\
(\mathrm{N} / \mathrm{mm})\end{array}$ \\
\hline 1 & 0,005 & 0.065 & 224,45 & 0,4711 & 476,44 \\
2 & 0,010 & 0.131 & 431,14 & 0,4502 & 957,67 \\
3 & 0,015 & 0.196 & 673,27 & 0,4654 & 1446,64 \\
4 & 0,020 & 0.262 & 894,27 & 0,4647 & 1924,39 \\
5 & 0,025 & 0.327 & 1123,60 & 0,4667 & 2407,53 \\
\hline
\end{tabular}

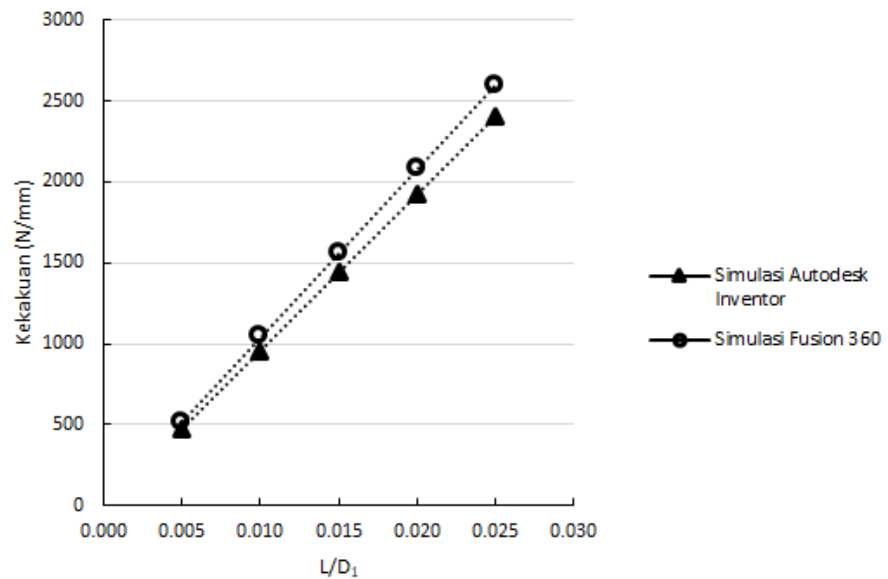

Gambar 3.3 Hubungan antara variasi geometri dan nilai kekakuan

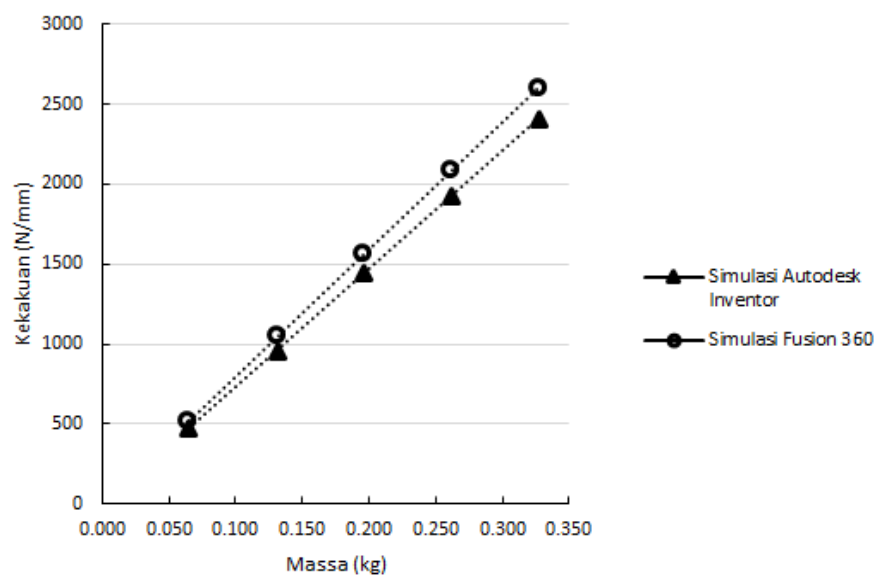

Gambar 3.4. Hubungan antara massa ring dan nilai kekakuan 
Hasil simulasi pemberian gaya pada geometri ring fiksasi eksternal dengan perangkat lunak Autodesk Inventor dan Fusion 360 yang disajikan pada Gambar 3.3 menunjukan bahwa nilai $L$ pada ring memengaruhi kekakuan. Hasil simulasi pada kedua perangkat lunak tersebut menunjukan bahwa semakin besar nilai $L$ maka kekakuan ring pada fiksasi ekstenal akan naik. Kenaikan nilai kekakuan ring karena pengaruh ketebalan ring tersebut bersifat linier. Ketebalan ring fiksasi eksternal mempengaruhi massa ring tersebut. Semakin tebal ring pada fiksasi eksternal massa perangkat tersebut semakin besar. Grafik pada Gambar 3.4 hasil simulasi menggunakan Autodesk Inventor dan Fusion 360 menunjukan bahwa semakin besar massa ring fiksasi eksternal nilai kekakuan akan naik. Nilai kekakuan ring fiksasi eksternal dipengaruhi gaya yang diberikan pada geometri dan displacement yang terjadi. Gaya yang diperlukan agar nilai von mises pada geometri mencapai nilai yield material tersebut semakin besar jika ketebalan ring semakin tebal. Hasil simulasi Autodesk Inventor dan Fusion 360 menunjukan bahwa hubungan gaya dengan ketebalan ring bersifat linier seperti yang ditampilkan pada Gambar 3.5. Gaya tersebut menghasilkan displacement pada geometri. Simulasi dengan Autodesk Inventor dan Fusion 360 menunjukan bahwa variasi ketebalan ring tidak terlalu berpengaruh pada displacement yang dihasilkan. Hubungan antara ketebalan ring dan displacement yang dihasilkan ditampilkan pada Gambar 3.6.

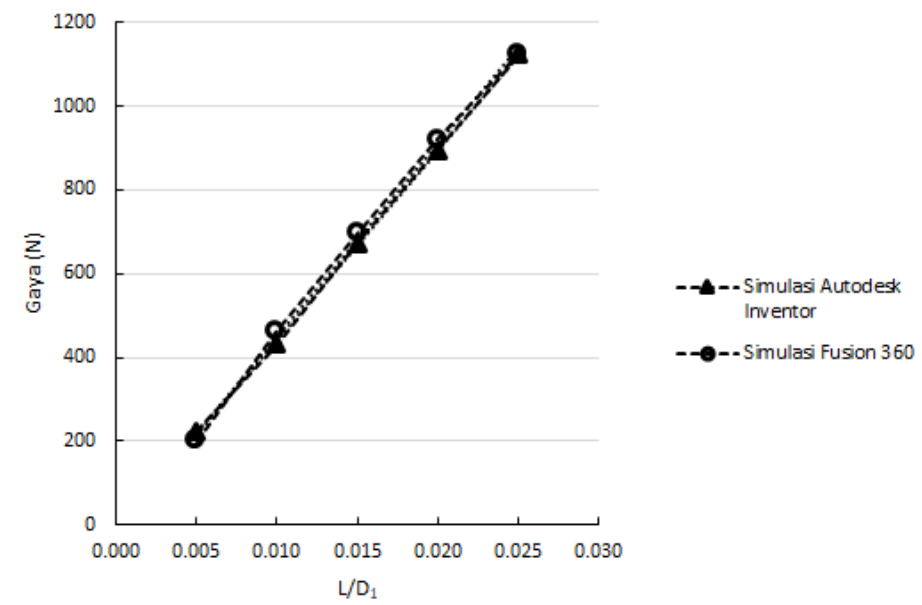

Gambar 3.5. Hubungan antara variasi geometri dan gaya

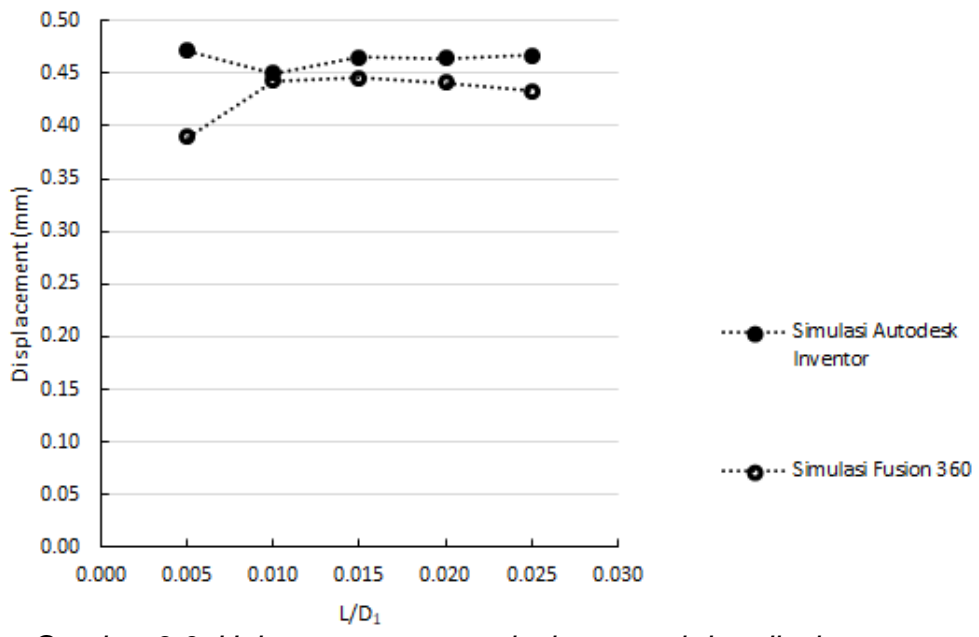

Gambar 3.6. Hubungan antara variasi geometri dan displacement

Ketebalan ring fiksasi eksternal mempengaruhi gaya yang dibutuhkan agar komponen tersebut mengalami luluh. Semakin tebal ring fiksasi, gaya yang dibutuhkan semakin besar. Ketebalan ring fiksasi tidak terlalu berpengaruh pada displacement yang terjadi ketika 
komponen tersebut luluh sehingga nilai kekakuan ring fiksasi dipengaruhi oleh ketebalan perangkat tersebut. Penambahan ketebalan ring fiksasi eksternal untuk meningkatkan kekakuan akan meningkatkan kestabilan posisi fracture, tetapi penambahan massa perlu diperhitungkan agar tidak menganggu penguna.

\section{Kesimpulan}

Ketebalan ring fiksasi eksternal mempengaruhi massa perangkat tersebut. Ketebalan ring fiksasi eksternal akan memengaruhi nilai gaya yang dibutuhkan agar perangkat tersebut luluh. Semakin tebal komponen tersebut gaya yang dibutuhkan akan semakin besar dan begitu juga sebaliknya. Hubungan gaya dan ketebalan ring bersifat linier. Ring yang diberi pembebanan berupa gaya akan menghasilkan displacement. Displacement yang terjadi ketika ring mengalami luluh nilainya relatif sama meskipun ketebalan ring tersebut bervariasi. Perbedaan kebutuhan gaya pada setiap variasi ketebalan ring dan nilai displacement yang relatif sama memengaruhi nilai kekakuan komponen tersebut. Kekakuan ring fiksasi ekstenal dapat ditambah dengan menaikan nilai ketebalan perangkat tersebut karena semakin tebal perangkat tersebut gaya yang dibutuhkan agar luluh semakin besar dan nilai displacement yang terjadi relatif sama walaupun ketebalannya berbeda. Hubungan ketebalan dan kekakuan tersebut didapatkan dari hasil simulasi pada variasi L/D 0,005 sampai dengan 0,025 .

\section{DAFTAR PUSTAKa}

[1] W. M. Murphy, AO Principles of Fracture Management. Stuttgart, 2000.

[2] X. Xu, X. Li, L. Liu, and W. Wu, "A meta-analysis of external fixator versus intramedullary nails for open tibial fracture fixation," Journal of Orthopaedic Surgery and Research, vol. 9, no. 1, p. 75, 2014.

[3] S. Leader, G. Pathak, F. Orth, S. Leader, and G. Pathak, "Military external fixation of fractures," ADF Health, vol. 2, pp. 24-28, 2001.

[4] M. B. Sternick, D. Dallacosta, D. A. Bento, and M. L. do Reis, "Relationship between rigidity of external fixator and number of pins : computer analysis using finite elements," Revista Brasileira de Ortopedia (English Edition), vol. 47, no. 5, pp. 646-650, 2012.

[5] D. P. Moss and N. C. Tejwani, "Biomechanics of external fixation," Bulletin of the NYU Hospital for Joint Diseases, vol. 65, no. 4, pp. 294-299, 2007.

[6] F. Magerl, The External Fixator. Berlin: Springer-Verlag, 1985.

[7] ASTM, Standard Specification and Test Methods for External Skeletal Fixation Devices, vol. 03. 1998.

[8] L. Yang, C. Weinberger, and Y. T. Shah, "Finite element analysis on horizontal vessels with saddle supports," Comput. Struct., vol. 52, no. 3, pp. 387-395, 1994.

[9] N. Pervan, E. Mesic, M. Colic, and V. Avdic "Stiffness analysis of the sarafix external fixator of composite materials," International Journal of Engineering \& Technology, vol. 5, no. 1, pp. 20-24, 2016.

[10] K. Yang and Y. Ren, "Nickel-free austenitic stainless steels for medical applications," Science and Technology of Advanced Materials, vol. 11, no.1, p. 014105, 2010.

[11] ASTM, Standard Specification for Chromium and Chromium-Nickel Stainless Steel Plate, Sheet, and Strip for Pressure Vessels and for General Applications, 2004. 